DANUTA PirÓG

Uniwersytet Pedagogiczny w Krakowie

\title{
Usługi edukacyjne na poziomie akademickim w kontekście wymagań rynku pracy*
}

Transformacja ustrojowa w Polsce przyniosła, oprócz oczywistych korzyści, szereg negatywnych konsekwencji. Jednym z kluczowych problemów społeczno-gospodarczych jest zjawisko bezrobocia, które nie omija także ludzi legitymujących się wyższym wykształceniem. Czynnikami, które mają największy wpływ na zmiany sytuacji na polskim rynku pracy, są m.in.: niedawne przystapienie do struktur Unii Europejskiej, globalizacja, transformacja społeczno-gospodarcza, rozwój technologii informacyjnych, reformy systemu edukacji, wzrost znaczenia wiedzy i wykształcenia, zwiększona konkurencyjność, masowość i stosunkowo łatwy dostęp do edukacji na poziomie wyższym (Denek i in. 2001; Orczykowska 2006).

Wielu naukowców postrzega majoryzowanie zagadnienia wymagań rynku pracy wobec absolwentów, oczekiwań absolwentów wobec rynku pracy i oceny ich zdolności do zatrudnienia jako spłycenie edukacji na poziomie wyższym do aspektów zawodowych i jako zagrożenie tradycyjnych wartości akademickich. Nadal w Polsce i za granicą istnieją zwolennicy poglądu, iż koncepcje programowe studiów nie mają być odpowiedzią na potrzeby rynku pracy, ale podążać za rozwojem myśli naukowej i zainteresowaniami młodzieży (Gedye, Chalkley 2006; Jawor 2002; Karwowski 2003; Paśko 2008).

Zwolennicy takich poglądów sądzą, iż sytuacja, w której student edukuje się w kierunku najbardziej odpowiadającym wyłącznie jego pasjom, wydaje się być rozwiązaniem idealnym, a wyposażenie studentów w liczne kompetencje merytoryczne i formalne jest celem $\mathrm{i}$ istotą edukacji akademickiej oraz stanowi wystarczający wkład uczelni w przygotowanie absolwenta do znalezienia się na rynku pracy. Pogląd taki nie uwzględnia jednak dynamicznych zmian roli usług (w tym usług edukacyjnych na poziomie akademickim) w rozwoju społeczno-gospodarczym i faktu, iż jednym z istotnych dążeń współczesnego szkolnictwa wyższego powinno być wyedukowanie absolwentów odnoszących sukcesy na rynku zawodowym i posiadających duży udział w kreowaniu liczącej się pozycji pracodawcy. Takie aspiracje mają coraz częściej sami kandydaci na studia, dla których priorytetem w wyborze kierunku jest ocena prawdopodobieństwa uzyskania zatrudnienia po zakończeniu kształcenia. Doświadczenia krajów Europy Zachodniej dowodzą, że w perspektywie kilkunastu lat ważne jest projektowanie takiej wizji studiów wyższych, by kompetencje absolwentów były jak najbliższe wymogom stawianym przez pracodawców.

* Praca naukowa finansowana ze środków budżetowych na naukę w latach 2010-2012 jako projekt badawczy nr N N114 076739 


\section{KSZTALCENIE AKADEMICKIE A WYMAGANIA RYNKU PRACY}

Rynek pracy, rozumiany jako miejsce konfrontacji podaży pracy z popytem na pracę, ulega ciagłym przeobrażeniom. W idealnym obrazie między gospodarką krajową, rynkiem pracy oraz szkolnictwem wyższym powinny istnieć zależności będące faktycznym odwzorowaniem równowagi podaży i popytu na pracę. Wówczas edukacja i gospodarka tworzą układ naczyń połączonych, a przemiany w gospodarce i zmienne zapotrzebowanie na określone kwalifikacje wyznaczają drogę zmian w edukacji (Bogaj 2000).

Realizowane dotychczas strategie programowe przyczyniły się do postrzegania wielu kierunków studiów jako przepustki do pracy w zawodach nisko płatnych lub wręcz jako ten typ studiów, który nie sprzyja uzyskaniu pracy. W badaniach popytu na pracę wyrażonego prasowymi ofertami pracy wyraźnie zaznacza się poszukiwanie pracowników (specjalistów) z dziedzin nauk technicznych i niemal nie zauważa się zainteresowania absolwentami najpopularniejszych kierunków studiów, tj. zarządzania i marketingu oraz kierunków pedagogicznych. Ekspansję przeżywały głównie kierunki, które poza popularnością wśród maturzystów, cechują się jeszcze relatywnie niskimi kosztami edukacji. Istotnym powodem takiej sytuacji jest fakt, iż niezamożne społeczeństwo nie jest w stanie realizować zakupu usług edukacyjnych na drogich kierunkach (Minkiewicz 2001).

Konfrontacja udziału studentów według grup kierunkowych z danymi o popycie na rynku pracy pokazuje, że ewolucja kierunków studiów następuje zbyt wolno w stosunku do zmian, a ponadto selektywnie. Jednocześnie trudno postawić jednoznaczną diagnozę jaka struktura kierunkowa studiów odpowiadałaby oczekiwaniom rynku pracy. Lepsze przygotowanie studentów do wymogów rynku pracy jest także utrudnione z powodu nieprzejrzystości samego rynku pracy. Niewiele wiadomo na temat przewidywanych trendów w zatrudnieniu osób z wyższym wykształceniem. Uczelnie na ogół są skazane na własną intuicję $\mathrm{w}$ tej kwestii, bowiem krajowy system prognozowania popytu na pracę jest w stadium zalążkowym (Sztanderska i in. 2005 a, b).

Do ważnych przyczyn niepowodzeń absolwentów studiów wyższych na rynku pracy należy tradycyjna, nie zawsze skorelowana z oczekiwaniami pracodawców koncepcja edukacji akademickiej. Brak spójności pomiędzy kompetencjami zdobywanymi w toku kształcenia na poziomie wyższym a realnymi potrzebami rynku pracy sprawia, że następstwa tego zjawiska poddawane są coraz częstszej krytyce społecznej. Kluczowym etapem w świadczeniu konkurencyjnych, nowoczesnych i dostosowanych do wymagań rynku pracy usług edukacyjnych na poziomie akademickim powinno być zatem konstruowanie właściwych programów nauczania i wdrażanie nowoczesnej koncepcji programowej (Donert 2007; Kopel 1999; Owen 2001).

W 1997 roku AIESEC Polska przeprowadził badania, których celem było poznanie oczekiwań pracodawców oraz studentów wobec szkolnictwa wyższego. Przebadano 874 studentów III i IV roku kierunków ekonomicznych kilkunastu uczelni w kraju (głównie kierunku zarządzanie i marketing) oraz 226 przedsiębiorców z całego kraju. Jednym z głównych celów badania było uzyskanie odpowiedzi, jakimi cechami powinien charakteryzować się i co powinien umieć absolwent uczelni wyższej ubiegający się o pracę. Pracodawcy na pierwszym miejscu wskazywali systematyczność, kolejno umiejętność rozwiązywania problemów, łatwość przystosowania się do nowych sytuacji, opanowanie w sytuacjach stresowych, operatywność, umiejętność pracy w zespole, umiejętność realizacji własnych celów, umiejętność wykorzystania teorii w praktyce, zdolności analityczne oraz kreatywność. 
Badania UNESCO wskazują, iż pracodawcy zatrudniający absolwentów oczekują od nich kompetencji opartych na 3 równorzędnych składnikach: wiedzy ogólnej, wiedzy praktycznej i umiejętnościach społecznych oraz komunikacyjnych, takich jak umiejętność pracy w zespole, inspirujące przywództwo, znajomość języków obcych, zaangażowanie, solidność i wytrwałość (Kluza, Kluza 1998).

Badania tuningowe z roku 2002, dotyczące pożądanych przez pracodawców umiejętności u absolwentów studiów z zakresu geografii, geologii i ochrony środowiska, przeprowadzone w dwunastu krajach (Estonia, Francja, Niemcy, Grecja, Islandia, Irlandia, Malta, Holandia, Polska, Słowacja, Hiszpania, Wielka Brytania), pozwoliły stworzyć zestaw kluczowych kompetencji, które pracodawcy cenią najwyżej u potencjalnych pracowników. Są to kolejno:

1. Umiejętność analizy i syntezy

2. Umiejętność stosowania wiedzy w praktyce

3. Umiejętność pracy w grupie

4. Kreatywność

5. Umiejętność poszukiwania informacji w różnych źródłach

6. Umiejętność rozwiązywania problemów

7. Umiejętności badawcze

8. Umiejętność planowania czasu

9. Umiejętność stosowania technologii informacyjnej

10. Umiejętności autoprezentacji oraz poprawnego pisemnego i ustnego przekazywania komunikatów (Donert 2007)

Pilotażowe badania oczekiwań małopolskich pracodawców wobec absolwentów studiów wyższych pokazały, iż za najważniejszą kompetencję formalną uznali oni znajomość zasad zastosowania wiedzy teoretycznej w praktyce, umiejętność posługiwania się technologiami informacyjnymi, umiejętność wyszukiwania informacji w różnych źródłach oraz wykorzystanie przygotowania teoretycznego w działaniach praktycznych (tab. 1).

Porównując oczekiwania pracodawców europejskich i małopolskich wobec absolwentów studiów geograficznych można zauważyć liczne podobieństwa. Obie badane grupy pracodawców cenią u swoich przyszłych pracowników konkretne kompetencje formalne i merytoryczne, $\mathrm{tj}$. stosowanie wiedzy teoretycznej w praktyce, poszukiwanie informacji czy rozwiązywanie problemów. Pracodawcy małopolscy znacznie wyżej niż europejscy cenili sobie umiejętności posługiwania się technologiami informacyjnymi. Obie grupy respondentów, oprócz wymienionych umiejętności, oczekiwali od kandydatów do pracy wykazywania się określonymi cechami osobowościowymi i postawami absolwentów - przede wszystkim kreatywnością, odpowiedzialnością, troską o jakość efektu pracy, otwartością na nowe zadania. 
Tab. 1. Ranking przydatności w pracy umiejętności formalnych absolwentów studiów geograficznych w opinii badanych pracodawców

\begin{tabular}{|c|c|c|c|c|c|c|c|c|c|c|c|}
\hline \multirow{2}{*}{ Umiejętności formalne } & \multicolumn{10}{|c|}{ Skala $1-10$} & \multirow{2}{*}{$\begin{array}{l}\text { SUMA } \\
\text { (wagi) }\end{array}$} \\
\hline & 1 & 2 & 3 & 4 & 5 & 6 & 7 & 8 & 9 & 10 & \\
\hline $\begin{array}{l}\text { Znajomość zasad zastosowania wiedzy } \\
\text { teoretycznej w praktyce }\end{array}$ & 6 & 5 & 2 & & 2 & 2 & & & 2 & 2 & 153 \\
\hline $\begin{array}{l}\text { Umiejętność posługiwania się technologiami } \\
\text { informacyjnymi }\end{array}$ & 2 & 4 & 3 & 4 & 4 & 1 & & 2 & & 1 & 145 \\
\hline $\begin{array}{l}\text { Umiejętność wyszukiwania informacji } \\
\text { w różnych źródłach }\end{array}$ & 2 & 2 & 4 & 3 & 1 & 2 & 1 & & 3 & 4 & 128 \\
\hline $\begin{array}{l}\text { Wykorzystanie przygotowania teoretycznego } \\
\text { w działaniach praktycznych }\end{array}$ & 7 & 3 & & 1 & & & & & 2 & 2 & 114 \\
\hline Odpowiedzialność & 1 & 4 & 1 & 1 & 2 & 3 & 2 & 2 & & 1 & 104 \\
\hline Kreatywność & 4 & & 2 & 3 & & & 2 & 2 & 3 & 1 & 102 \\
\hline Troska o jakość efektu pracy & & & 1 & 1 & 7 & 2 & 3 & 1 & 1 & 1 & 87 \\
\hline Umiejętność rozwiązywania problemów & & 1 & 1 & 1 & 3 & & 4 & 1 & 3 & & 70 \\
\hline Znajomość języków obcych & 2 & 3 & 1 & 1 & & & & & 1 & 1 & 67 \\
\hline Planowanie i zarządzanie czasem & & & 2 & 3 & 1 & 2 & 2 & 1 & 1 & & 67 \\
\hline Umiejętność pracy w grupie & & 2 & 1 & & 2 & 2 & 2 & & 1 & 1 & 61 \\
\hline $\begin{array}{l}\text { Umiejętność analizy i syntezy procesów } \\
\text { i zjawisk }\end{array}$ & 1 & 2 & 2 & 1 & & 1 & 1 & & & & 60 \\
\hline Efektywna komunikacja interpersonalna & & & 1 & 1 & 3 & & 2 & 5 & & 2 & 60 \\
\hline Otwartość na nowe zadania & & & 1 & 3 & & 2 & 2 & 1 & 1 & 2 & 57 \\
\hline $\begin{array}{l}\text { Umiejętność samodzielnego podejmowania } \\
\text { decyzji }\end{array}$ & & 1 & 2 & 2 & & 2 & 1 & & & & 53 \\
\hline Zachowanie zasad etyki pracy & 1 & & 1 & & & 2 & 1 & 2 & 1 & 1 & 43 \\
\hline $\begin{array}{l}\text { Dokładność i precyzja w wykonywanych } \\
\text { zadaniach }\end{array}$ & & & & & 1 & 2 & 2 & 2 & & 1 & 32 \\
\hline $\begin{array}{l}\text { Umiejętność szybkiego dostosowania się } \\
\text { do nowych sytuacji }\end{array}$ & & & 1 & & & 1 & 1 & 1 & 1 & 3 & 29 \\
\hline $\begin{array}{l}\text { Umiejętność realizacji zadań } \\
\text { interdyscyplinarnych }\end{array}$ & & & & & & 2 & 1 & & 1 & & 17 \\
\hline $\begin{array}{l}\text { Otwartość na pracę w międzynarodowym } \\
\text { gronie }\end{array}$ & & & & 1 & & & & 2 & 1 & & 16 \\
\hline $\begin{array}{l}\text { Zdolność krytycznego myślenia i oceny siebie } \\
\text { i innych }\end{array}$ & & & 1 & & & & & & 1 & 1 & 13 \\
\hline $\begin{array}{l}\text { Umiejętność przekazywania wiedzy } \\
\text { w prosty i komunikatywny sposób }\end{array}$ & & & & 1 & & & & 2 & & & 13 \\
\hline $\begin{array}{l}\text { Znajomość zasad prowadzenia badań } \\
\text { terenowych }\end{array}$ & 1 & & & & & & & & & 1 & 12 \\
\hline $\begin{array}{l}\text { Sprawność w pisemnym i ustnym } \\
\text { posługiwaniu się językiem ojczystym }\end{array}$ & & & & & 1 & & & 2 & & & 12 \\
\hline
\end{tabular}




\begin{tabular}{|l|c|c|c|c|c|c|c|c|c|c|c|}
\hline $\begin{array}{l}\text { Umiejętność realizacji zadań związanych } \\
\text { z dyscypliną nauk geograficznych }\end{array}$ & & & & & 1 & & 2 & & 11 \\
\hline Szacunek dla innych kultur, ras, wyznań & & & & & & & 1 & 1 & 1 & 8 \\
\hline Zmysł przedsiębiorczy & & & & & & & & 1 & & 3 \\
\hline $\begin{array}{l}\text { Umiejętność planowania i realizowania } \\
\text { projektów }\end{array}$ & & & & & & & & & & & 0 \\
\hline Umiejętności badawcze & & & & & & & & & & & 0 \\
\hline Zdolności przywódcze & & & & & & & & & & & 0 \\
\hline Ostrożność
\end{tabular}

* wagi: pozycje 1 do 10 odpowiednio $10,9,8,7,6,5,4,3,2,1$ pkt

Źródło: Piróg, Piróg 2007, s. 640-641

\section{NOWOCZESNE KONCEPCJE PROGRAMU STUDIÓW}

Tradycyjny model tworzenia programów studiów, polegający głównie na interpretacji zapisów podstawy programowej przez kadrę naukowo-dydaktyczną danej jednostki w postaci zestawu przedmiotów, nie jest obecnie wystarczający. Nieodzowne jest nowe podejście, w którym propozycja programu studiów będzie wynikać bezpośrednio z krajowej struktury kwalifikacji, która indukuje standardy kształcenia warunkujące szczegółowe efekty kształcenia, rozumiane jako zestaw kluczowych umiejętności, postaw i wiedzy. Istotne jest dokonanie reorientacji celów kształcenia, polegającej na majoryzowaniu umiejętności i postaw zamiast encyklopedycznych i specjalistycznych faktów. Wąsko pojmowana wiedza szybko ulega dezaktualizacji za sprawą dużego tempa rozwoju techniki. Nadto maleje prawdopodobieństwo, by absolwenci przez cały okres aktywności zawodowej pozostali wierni swemu wyuczonemu zawodowi i wykorzystywali tym samym niemal wyłącznie specjalistyczną wiedzę. Dlatego w coraz większym stopniu zauważa się dążenie do określenia umiejętności i postaw, które pozwolą obywatelom na czynne uczestnictwo w tworzącym się społeczeństwie wiedzy. W centrum zainteresowania stawiane są relacje między edukacją a gospodarką. Coraz częściej mówi się o roli edukacji na każdym szczeblu kształcenia w kontekście rozwoju gospodarczego, w znacznym stopniu uzależnionego od sektora usług (Kluczowe... 2005).

Obecnie wiele uczelni wyższych w Polsce wdrożyło lub wdraża takie koncepcje programowe, które wyraźnie ogniskują się wokół efektów kształcenia. Należy jednak pamiętać, iż na projektowane w danej uczelni i na danym kierunku szczegółowe efekty kształcenia powinny mieć duży wpływ także takie aspekty, jak wizja i misja danej uczelni oraz, co wydaje się być niezwykle ważne, opinie pracodawców i innych interesariuszy. Efekty kształcenia, przedyskutowane i wynikające z głębokiej analizy potrzeb i wymagań standardów kształcenia, specyfiki uczelni oraz rynku pracy, powinny owocować elastycznym zestawem przedmiotów (kursów), które w miarę potrzeb mogą być modyfikowane w zakresie swojej oferty programowej (wzbogacane o kursy z nowego zakresu tematycznego) lub eliminowane z oferty programowej (ryc. 1, 2). 


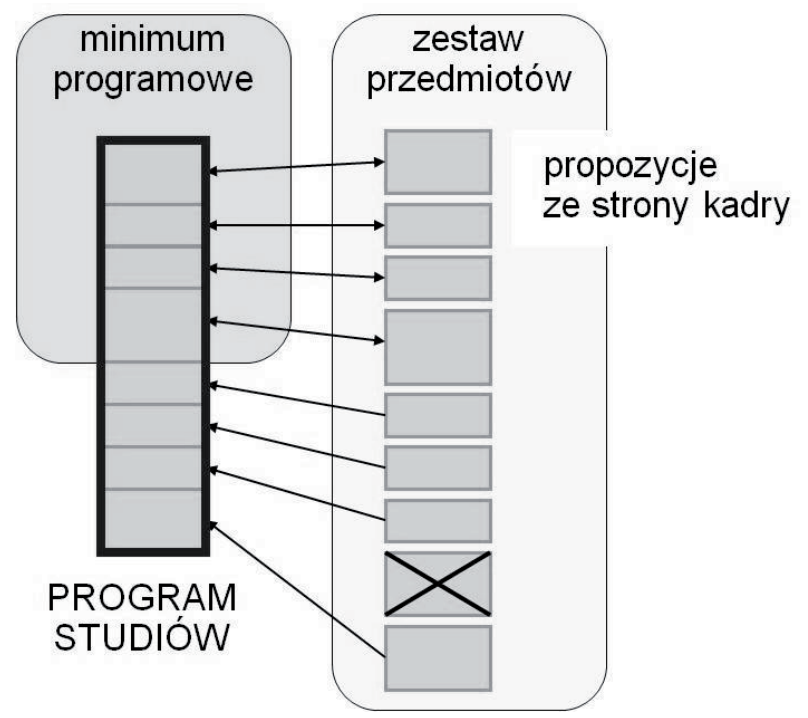

Ryc. 1. Konstrukcja programów studiów w ujęciu tradycyjnym Źródło: Kraśniewski 2008

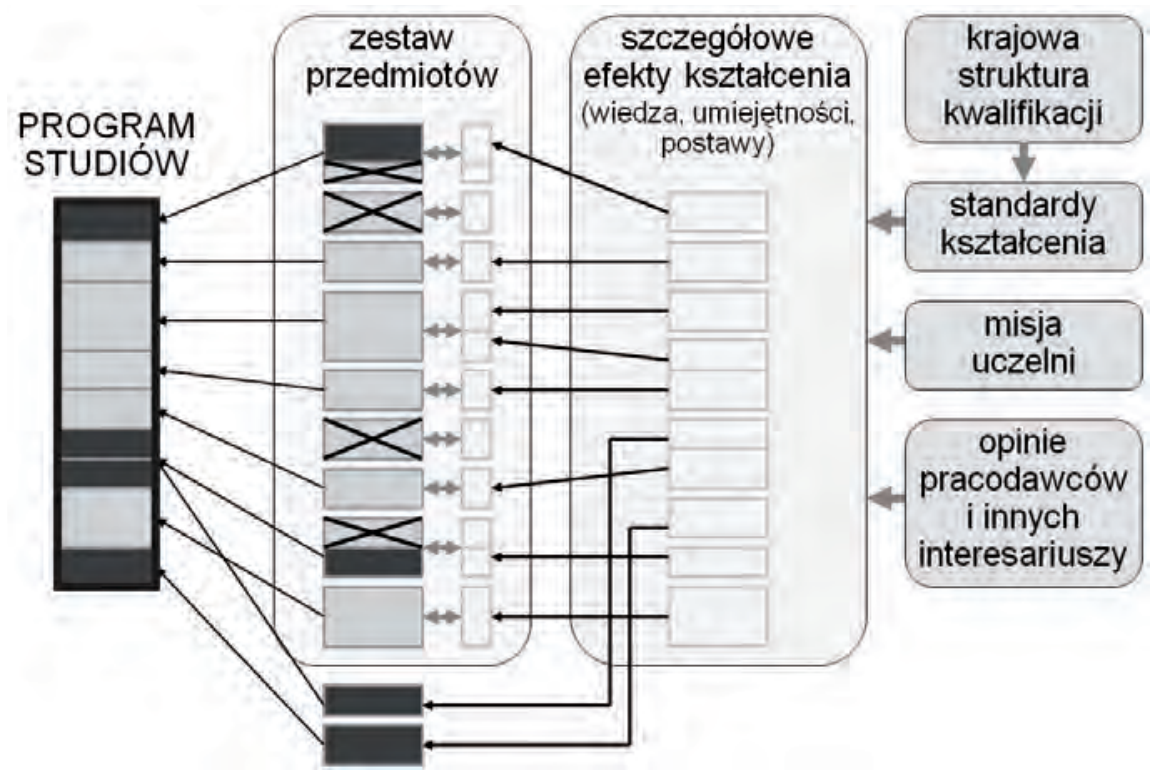

Ryc. 2. Konstrukcja programów studiów w ujęciu nowoczesnym

Źródło: Kraśniewski 2008

Skutkiem tak skonstruowanego programu studiów jest kreowanie koncepcji kształcenia hołdującej umiejętnościom praktycznym w miejsce wąskiej specjalizacji teoretycznej, ograniczaniu możliwości tworzenia programu zdominowanego interesami kadry nauczającej 
i ułatwieniu zaangażowania interesariuszy zewnętrznych - głównie pracodawców - co może owocować kwalifikacjami absolwentów, które uczynią ich konkurencyjnymi na trudnym rynku pracy. Warto szczególnie mocno podkreślić, iż bez udziału pracodawców w projektowaniu i realizowaniu programu studiów znacznie zmniejszają się szanse absolwentów na sprostanie wymaganiom rynku pracy po zakończeniu studiów. Poziom zatrudnienia absolwentów danego kierunku studiów i danej uczelni, konkurencyjność i sukces absolwenta na krajowym i międzynarodowym rynku pracy już jest w wielu krajach miarą jakości nauczania (Gedye, Chalkley 2006).

Procedura ta służyć powinna:

- czytelnemu opisowi kwalifikacji;

- majoryzowaniu kompetencji cenionych przez pracodawców i lepszemu rozkładowi kompetencji w całej populacji absolwentów;

- identyfikacji i eliminacji braków i redundacji w programie studiów;

- zwiększeniu możliwości eksperymentowania i wprowadzania innowacji w metodach nauczania;

- wymuszaniu lepszych i bardziej kompletnych mechanizmów oceny osiaggnięć studentów;

- ułatwieniu tworzenia wspólnych programów studiów (z innymi kierunkami lub uczelniami);

- ułatwieniu wymiany studentów (Kraśniewski 2008).

Wykształcenie wyższe zrealizowane w ujęciu nowoczesnym nie jest obecnie gwarancją uzyskania zatrudnienia w wybranym przez absolwenta miejscu pracy, ale optymalizuje jego szanse konkurowania z absolwentami innych kierunków i uczelni. Badania wykazują, że na rynku pracy zdominowanym przez sektor usługowy pracodawcy poza wiedzą, umiejętnościami kierunkowymi i specjalistycznymi coraz częściej domagają się od kandydatów do pracy cech takich, jak pewność siebie, zdolności interpersonalne, kreatywność i gotowość do przejmowania inicjatywy (Donert 2007; Gedye i in. 2004; Kopel 1999; Owen 2001; Piróg, Piróg 2007; Orczykowska 2006).

Jest to swego rodzaju nowa granica zbioru umiejętności i wielu nauczycieli akademickich o klasycznym podejściu do procesu kształcenia na poziomie wyższym z wahaniem angażuje się w wypracowywanie tej sfery, którą postrzegają jako cechy osobowości, a nie miarodajne efekty studiowania.

Przedstawione wyniki przeprowadzonych badań powinny stanowić istotne ogniwo w konstruowaniu nowoczesnych, zorientowanych na wymagania rynku pracy ofert programowych. W zakresie tworzenia zestawu kursów konieczne wydaje się być poświęcenie uwagi modernizacji i poszerzaniu kursów związanych z technologiami informacyjnymi. W zakresie realizacji wszelkich zajęć w toku studiów należy dołożyć szczególnych starań, by wykształcały i ćwiczyły u studentów umiejętności współpracy, kreatywności, posługiwania się literaturą obcojęzyczną. Spójne opanowanie zarówno klasycznego kanonu edukacji akademickiej, jak i nowoczesnej wizji studiowania nakierowanego na potrzeby rynku pracy powinno odbywać się zatem poprzez permanentne wkomponowanie w proces edukacyjny takich metod kształcenia, jak PBL (problem/project-based learning) - metodę projektów oraz WBL (work-based learning) - metodę praktycznego nabywania umiejętności. Kadra dydaktyczna powinna także stwarzać szanse i efektywnie inspirować młodzież do wymian studenckich, np. w ramach programów unijnych, które stanowią niezastąpiony sposób na kreowanie postaw otwartości, tolerancji i doskonalenie języków obcych. 
Nadto, przy ogromnej konkurencji na rynku pracy, nie mniej niż wiedza teoretyczna, dobrze wykształcone kompetencje merytoryczne i formalne oraz pożądane przez pracodawców postawy i zachowania, ważna jest także umiejętność poruszania się po rynku pracy, w tym przygotowania właściwej oferty aplikacyjnej, przeprowadzania skutecznej rozmowy kwalifikacyjnej, znajomość metod i technik docierania do poszukiwanych miejsc pracy. Obecnie dla studenta przygotowującego się do wejścia na rynek pracy ważna jest umiejętność konstruowania PDP - planu rozwoju osobowego (od ang. Personal Development Plan).

W Wielkiej Brytanii od roku akademickiego 2005/2006 w programach wszystkich typów i kierunków studiów obligatoryjnie wprowadzono kurs PDP. Rolą tego kursu jest wykształcenie u studentów umiejętności wyartykułowania swoich zalet i wyboru obszarów dalszego rozwoju zawodowego. W tym celu każdy student powinien mieć sposobność uświadomienia sobie osobistych celów i planów zawodowych, określenia dróg ich realizacji i rozpoznania własnych mocnych stron. Konieczne jest zatem rozwinięcie umiejętności planowania, tym razem oznaczającego rozpoznawanie, wprowadzanie, monitorowanie i ocenianie kolejnych kroków na drodze do osiagnnięcia celu (w tym przypadku uzyskania satysfakcjonującej pracy). Kolejnym niezbędnym krokiem jest doskonalenie technik komunikowania się poprzez komunikację bezpośrednią, pisemną, elektroniczną i telefoniczną oraz autoreklamy, rozumianej jako umiejętności zdefiniowania i promowania swojego własnego potencjału (Embedding 2001; Heron, Le Hathaway 2000; Jenkins, Healy 1995; Maguire, Guyer 2004; Struder 2006).

W toku realizowania celów PDP studenci, oprócz wskazanych umiejętności, powinni mieć okazję do wypracowania postawy otwartości, niezależności i większej pewności siebie oraz swoich możliwości. Zrozumienie procesu zarządzania karierą zawodową i umiejętnościami „przechodnimi” (CV, rozmowa o pracę itp.) pomaga studentom zarówno w ubieganiu się o pierwszą pracę, jak i w budowaniu podwalin swego późniejszego zawodowego rozwoju.

Istnieje wyraźna tendencja do włączania PDP do programu zajęć akademickich, najczęściej poprzez moduły realizowane przez kadrę akademicką przy wsparciu specjalistów instytucjonalnych biur. Przydatne może być także odwiedzanie miejsc pracy oraz zapraszanie potencjalnych pracodawców w celu podzielenia się ze studentami danego kierunku swoimi doświadczeniami biznesowymi i oczekiwaniami wobec przyszłych pracowników. W Polsce taką pomoc studentom w wejściu i efektywnym funkcjonowaniu na rynku pracy świadczyć mają akademickie biura karier. Warto jednak zastanowić się, czy nie należy dążyć do sprzężenia programu studiów z działalnością tych biur na rzecz optymalizacji szans absolwentów na rynku pracy (Kicior 2007).

\section{AUDYT PROGRAMU STUDIÓW W ASPEKCIE RYNKU PRACY}

Zestaw trafnie dobranych kursów i metod kształcenia to jeden z ważnych elementów prób sprostania wyzwaniom rynku pracy przez edukację akademicką. Kolejne składowe nowoczesnych koncepcji realizacji kształcenia na poziomie wyższym obejmują: jakość współpracy danego kierunku studiów z uczelnianym biurem karier, kontakty z potencjalnymi pracodawcami oraz rzetelne badanie losów absolwentów na rynku pracy i wykorzystywanie wniosków z tych badań do modyfikacji swojej oferty edukacyjnej.

Każdy, nawet opracowany w nowoczesny sposób program kursów akademickich nie jest pełną odpowiedzią na zmieniające się nieustannie wymagania rynku pracy i dlatego po- 
winien być cyklicznie poddawany skrupulatnemu audytowi. Takie praktyki stosowane są już od lat 80. m.in. w Wielkiej Brytanii. Dla grupy przedmiotów GEES - geography, earth and environmental studies (geografia i nauki o Ziemi) - prowadzony jest audyt programów kształcenia akademickiego pod kątem potrzeb rynku pracy jako stały element oceny jakości kształcenia. Audyt służy kontroli i ocenie poziomu działań danego kierunku studiów w aspekcie optymalnego przygotowania swoich absolwentów do wejścia na rynek pracy.

Audyt obejmuje cztery sekcje, czyli: ofertę programową kursów danego kierunku studiów; charakter i intensywność współpracy danego kierunku studiów z biurem karier uczelni; kontakty z potencjalnymi pracodawcami oraz badanie losów absolwentów na rynku pracy i wykorzystywanie wyników tych badań do korekt programowych.

Do audytu stosuje się kwestionariusz zbudowany z zestawu pytań, które są punktowane od 0 do 3 , gdzie 0 oznacza „nie występuje”, 1 - „,występuje w niewielkim stopniu”; 2 - „występuje w znacznym stopniu”; 3 - „występuje w bardzo dużym stopniu”.

Poniżej zamieszczono przykład kwestionariusza audytu koncepcji programowej studiów geograficznych na uniwersytecie w Plymouth. Zestaw pytań jest zestawem podstawowym do rozpoczęcia kontroli i oceny wizji realizowanych w danej jednostce studiów i może stanowić bazę do jego rozbudowy według potrzeb i specyfiki uczelni oraz poddanego audytowi kierunku.

Audyt służy wyodrębnieniu mocnych i słabych stron koncepcji programowej, a także ułatwia wskazanie niedoborów lub jej braków. Gruntowna analiza specyfiki realizowanego programu studiów w danej jednostce dydaktycznej w zaproponowanych powyżej aspektach może w znaczny sposób pomóc w dokonaniu wielostronnej oceny jakości oferty edukacyjnej w odniesieniu do wyzwań rynku pracy.

Wiele kwestii będących elementem oceny programu studiów nie jest trwałym i powszechnym elementem filozofii kształcenia na poziomie wyższym w Polsce. W zakresie programu studiów nie występuje powszechnie realizowanie kursu PDP, czyli budowania przez studentów planu rozwoju zawodowego. Także współpraca danego kierunku studiów z biurami karier wydaje się mieć charakter luźny i incydentalny. Nie jest trwałą tradycją konstruowanie programów kursów przy współpracy z kadrą biur karier, podobnie jak z potencjalnymi pracodawcami. Coraz częściej spotkać można natomiast prace dyplomowe będące konkretną odpowiedzią na zapotrzebowanie zgłaszane przez wybranych pracodawców. Najsłabszym ogniwem programów studiów w Polsce wydaje się być rola doświadczeń absolwentów na rynku pracy w konstrukcji i modernizacji tychże programów. Badanie losów swoich absolwentów studiów wyższych przez uczelnie jest sporadyczne. Wieloaspektowe procesy transformacji gospodarczej lat 90., gruntowna zmiana procesu zatrudniania, poszukiwania pracy, pojawiający się proces bezrobocia, a także zmiany w systemie szkolnictwa, nie znalazły niestety szerokiego odzwierciedlenia w badaniach relacji wykształcenie-szanse na rynku pracy. W tym okresie ukazały się trzy publikacje książkowe podejmujące aspekt losów absolwentów i rynku pracy dla absolwentów uczelni wyższych. Pierwsze z opracowań to tom materiałów pokonferencyjnych, dotyczący absolwentów bibliotekoznawstwa i informacji naukowej, ale głównie prezentujący komunikaty o stanie kadrowym wybranych bibliotek w Polsce (Rynek... 1997). Druga książka ukazuje losy absolwentów SGH na rynku pracy. Badania przeprowadzono w 2006 r. wśród absolwentów z lat 19962004. Do celów badań należało m.in. określenie wpływu studiów na przebieg kariery zawodowej i usprawnienie metodyki badań losów absolwentów (Absolwenci... 2008; Minkiewicz 2001). 
Tab. 2. Audyt koncepcji programowej studiów pod kątem wyzwań rynku pracy

\section{A. Kierunek studiów, oferta programowa}

1. Czy na kierunku są regularnie prowadzone działania mające na celu promowanie studentów na lokalnym i krajowym rynku pracy?

2. Jeśli tak, czy studenci są informowani i czynnie angażowani w te działania?

3. Czy programy kursów majoryzują kluczowe kompetencje?

4. Czy i w jakim stopniu oferta programowa służy rozwijaniu świadomości studenta $\mathrm{w}$ zakresie pożądanych kompetencji na rynku pracy?

5. Czy na kierunku w ramach oferty programowej występują wyraźnie elementy systemu PDP?

6. Czy studenci są czynnie zaangażowani w ocenianie oferty programowej na wybranym przez nich kierunku studiów?

7. Czy koncepcja programowa zawiera i promuje work-based learning?

8. Czy występuje w ofercie programowej miejsce na zdobywanie i doskonalenie takich umiejętności, jak aktywne poszukiwanie pracy, konstruowanie CV, prowadzenie rozmów o pracę itd.?

\section{B. Biura karier}

1. Czy jest bliska i efektywna współpraca pomiędzy kierunkiem studiów a biurem karier uczelni?

2. Czy pracownicy biura karier biorą czynny udział w pracach nad konstruowaniem programów kształcenia akademickiego?

3. Czy studenci danego kierunku studiów są zachęcani do korzystania z pomocy biura karier?

4. Jak duży odsetek aktualnych studentów deklaruje, że korzystało lub korzysta $\mathrm{z}$ pomocy biura karier?

\section{Kontakty $z$ potencjalnymi pracodawcami}

1. Czy potencjalni pracodawcy biorą czynny udział w pracach nad konstruowaniem programów kształcenia akademickiego?

2. Czy pracodawcy są zaangażowani w realizowanie oferty programowej poprzez prezentacje, spotkania ze studentami, prowadzenie wybranych zajęć lub części zajęć?

3. Czy studenci są informowani o różnego typu instytucjach i organizacjach działających na rzecz poszukujących pracy?

4. Czy prace licencjackie, dyplomowe są odpowiedzią na zapotrzebowanie pracodawców, mają znaczenie aplikacyjne i są próbą rozwiązania konkretnych (zamówionych) zadań?

5. Czy pracodawcy są stałym elementem procesu dydaktycznego , np. poprzez prelekcje, studia przypadków?

D. Absolwenci na rynku pracy

1. Czy kadra dydaktyczna jest zapoznawana z losami swoich absolwentów na rynku pracy?

2. Czy studenci są zapoznawani z losami swoich kolegów - absolwentów na rynku pracy?

3. Czy jednostka prowadząca dany kierunek studiów samodzielnie i regularnie prowadzi badania nad losami zawodowymi swoich absolwentów? 
4. Czy absolwenci, którzy odnieśli sukces na rynku pracy, są zapraszani do jednostki prowadzącej dany kierunek studiów w celu podzielenia się swoimi doświadczeniami z aktualnymi studentami?

5. Czy jednostka prowadzi na bieżąco kontakt ze swoimi absolwentami poprzez stronę www?

6. Czy absolwenci są czynnie zaangażowani w realizowanie oferty programowej poprzez prezentacje, spotkania ze studentami, prowadzenie wybranych zajęć lub części zajęć?

Źródło: Gedye, Chalkley 2006

Ostatnią dotychczas na rynku publikacją książkową, częściowo podejmującą zagadnienie absolwentów szkoły wyższej, jest opracowanie pt. Analiza losów zawodowych absolwentów - narzędzia i metody w krajach Unii Europejskiej $i$ w Polsce pod redakcją J. Żyra. Autorzy przedstawiają procedury badania losów absolwentów szkół wyższych w trzech krajach Unii Europejskiej oraz ciekawe wyniki badań sondażowych absolwentów Politechniki Krakowskiej, przeprowadzone w 2007 r. Badania te dotyczyły planów i oczekiwań studentów ostatniego roku studiów wobec rynku pracy. Wyniki te nie zostały jednak ponowione wśród respondentów po ukończeniu studiów, stąd informują one głównie o wyobrażeniach studentów co do ich przyszłości zawodowej, a nie realnej sytuacji na rynku pracy (Analiza 2007).

Oprócz opracowań książkowych i monograficznych, opublikowano kilkanaście bardzo ciekawych artykułów, m.in. na temat badań nad losami absolwentów geografii WSP w Kielcach (Biernat 1997), absolwentów Akademii Muzycznej we Wrocławiu (Tomaszek-Plewa 2001), absolwentów AWF w Warszawie (Jaworski, Ryszkowska 2002), absolwentów turystyki AWF w Krakowie (Kruczek 2003) oraz języków obcych (Aleksandrowicz-Pędich, Lewicka-Mroczek 2003).

W innych krajach badania te podejmowane są cyklicznie i instytucjonalnie, np. przez HESA - Higher Education Statistic Agency w Wielkiej Brytanii, HEA - Higher Education Authority w Irlandii czy Alma Laurea we Włoszech (Antonelii i in. 2009).

Czasochłonność i kapitałochłonność takich badań sprawiają, iż w Polsce wciąż można uznać tę kwestię uwzględnioną w proponowanym audycie za niebyłą.

Ważnym uzupełnieniem tak przeprowadzonej oceny programów przez kadrę naukowo-dydaktyczną jest zbadanie opinii absolwentów o jakości kształcenia w toku studiów, które ukończyli w kontekście wymagań rynku pracy.

\section{ZAKOŃCZENIE}

Rynek pracy w Polsce ulega ciagłym zamianom. Dominacja sektora usług, gwałtowny postęp technologii i organizacji w miejscu pracy powoduje, że ludzie nie mogą już oczekiwać pracy na jednej posadzie przez całe swoje życie i linearnego charakteru przebiegu ich kariery (Harvey 2002). Definicja posad typowych dla absolwentów uległa zatarciu, jako że sami zainteresowani coraz częściej zatrudniają się w małych i średnich firmach, w wolnych zawodach lub zakładają własną działalność gospodarczą (Harvey, Locke, Morey 2002; Elias i in. 1999). 
Spojrzenie na edukację akademicką jako usługę, mającą za zadanie sprostać wymaganiom rynku pracy, powoduje, iż celem tego etapu kształcenia powinno być nabycie tzw. zdolności do zatrudnienia (ang. employability), czyli takiego zestawu umiejętności, które sprawią, iż absolwent bardziej niż inni rokuje, iż zostanie zatrudniony i odniesie sukces w wybranym przez siebie zawodzie, przynosząc tym samym korzyści sobie, pracodawcy, społeczeństwu i gospodarce (Rooney i in. 2006).

W sferze polskiego szkolnictwa wyższego rozwój zdolności do pracy nie jest priorytetem, bowiem, jak wspomniano w niniejszym opracowaniu, takie podejście do edukacji było dotychczas przypisane kształceniu zawodowemu na poziomie średnim i zawodowym. Studia literatury tematu pokazują, iż tworzenie programów kształcenia akademickiego z uwzględnieniem potrzeb rynku pracy nie musi stać w sprzeczności z tradycyjnymi akademickimi wartościami. W procesie tym należy zdawać sobie sprawę z potrzeby niemal nieustannego modelowania oferty programowej i mieć świadomość, iż każdy, najlepszy nawet program kształcenia należy cyklicznie oceniać i modyfikować. Kadra naukowo-dydaktyczna musi zaakceptować fakt, iż jeśli dany program kształcenia akademickiego ma być nowoczesny, sprzężony z wymogami rynku pracy, konkurencyjny, atrakcyjny i korzystny dla studenta z punktu widzenia pozyskania satysfakcjonującej pracy, to będzie każdorazowo wymagał prac naprawczych po okresie około trzech-czterech lat. W toku tych prac niezbędna będzie przede wszystkim identyfikacja i eliminacja braków oraz redundacja w programie, unowocześnianie miejsc i celów praktyk zawodowych, technik zarządzania karierą zawodową, kluczowych kompetencji i planowania rozwoju osobistego studenta. Niemniej jednak studenci będą musieli przyswoić sobie przynajmniej niektóre konieczne doświadczenia i cechy poza tokiem studiów - albo poprzez inne aspekty życia studenckiego albo poprzez takie aktywności, jak praca na pół etatu, wolontariat, wymiany studenckie czy podróże. Wówczas dopiero studia wyższe, podczas których wykładowcy rzetelnie wyposażają studentów w szeroki wachlarz kompetencji i skutecznie inspirują do przyjmowania pożądanych postaw cenionych przez większość pracodawców, w znacznym stopniu zwiększą perspektywy rozwoju ich karier na polskim i europejskim rynku pracy.

\section{Literatura}

Absolwenci SGH na rynku pracy, red. B. Minkiewicz, P. Błędowski, 2008, SGH, Warszawa.

Aleksandrowicz-Pędich L., Lewicka-Mroczek E., 2003, Dziesięć lat później: losy zawodowe absolwentów pierwszego rocznika studentów NKJA w Biatymstoku, Języki Obce w Szkole, nr 3, s. 52-54.

Analiza losów zawodowych absolwentów - narzędzia i metody w krajach Unii Europejskiej i w Polsce, red. J. Żyra, 2007, Wyd. Biuro Karier, Instytut Ekonomii, Socjologii i Filozofii Politechniki Krakowskiej, Kraków.

Antonelli G., Camillo F., Cammelli A., Di Francia A., Ghiselli S., Sgarzi M., 2009, Graduates' employment and employability after the 'Bologna Process' reform. Evidence from the Italian experience and methodological issues, University of Lubljana, Slowenia.

Biernat M., 1997, Losy zawodowe absolwentów geografii na tle losów absolwentów Wydzialu Matematyczno-Przyrodniczego WSP w Kielcach w latach 1990-1995, Studia Kiel. Ser. Geolog.Geogr., $\mathrm{nr} 2$.

Bogaj A., 2000, Kształcenie ogólne. Między tradycją a nowoczesnościq, Wyd. IBE, Warszawa .

Denek K., Przyszczypkowski K., Urbański-Korż R., 2001, Aksjologiczne podstawy edukacji, Wyd. Edytor, Poznań-Torun. 
Donert K., 2007, Aspects of the state of geography in european higher education. Tuning geography: a report of findings and outcomes, Liverpool Hope University.

Embedding careers education in the curricula of geography, earth and environmental science students, 2001, Planet, no 1.

Gedye S., Chalkley B., 2006, Employability within geography, earth and environment al science, GEES, University of Plymouth.

Gedye S., Fender E., Chalkley B., 2004, Geography and jobs: undergraduate expectations and graduate experience, Journal of Geography in Higher Education, 28, no 3, s. 381-396.

Harvey L., Locke W., Morey A., 2002, Enhancing employability, recognising diversity: making links between higher education and the world of work. Universities UK and the higher education careers service unit.

Elias P., McKnight A., Pitcher J., Purcell K., Simm C., 1999, Moving on: graduate careers. Three years after graduation (www.prospects.ac.uk) .

Jawor A., 2002, Szanse absolwentów szkót wyższych na rynku pracy: seminarium w IPiSS, Polityka Społeczna, nr 3 s. 37-38.

Jaworski Z., Ryszkowska E., 2002, Specjalność a losy zawodowe absolwentów warszawskiej AWF z lat 1950-1994, Wychowanie Fizyczne i Zdrowotne, nr 6/7, s. 19-24.

Jenkins A., Healy M., 1995, IGHE Symposium: linking the geography curriculum to the worlds of industry, commerce and public authorities, Journal of Geography in Higher Education, 19, no 2, s. $177-181$.

Karwowski L., 2003, Oczekiwania pracodawców w zakresie kompetencji absolwentów, Rynek Pracy, nr 5, s. 141-149.

Kicior A., 2007, Problemy zatrudnienia absolwentów szkót wyższych, Edukacja, nr 3, s. 11-18.

Kluczowe kompetencje, 2005, Fundacja Rozwoju Systemu Edukacji, Warszawa.

Kluza K., Kluza S., 1998, Szkolnictwo wyższe a rynek pracy, [w:] Studia wyższe - szansa na sukces?, ISB, Warszawa, s. 37-49.

Kopel J., 1999, Absolwenci na lokalnym rynku pracy z perspektywy pracodawców. Raport z badań, Wyd. WSZiM, Sosnowiec.

Kraśniewski A., 2008, Efekty ksztatcenia a konkurencyjność polskiego szkolnictwa wyższego, Konferencja UW-FRSE, Warszawa.

Kruczek Z., 2003, Losy zawodowe magistrów turystyki absolwentów AWF w Krakowie, Folia Turistica, nr 14, s. 43-55.

Maguire S., Guyer C., 2004, Preparing Geography, Earth and Environmental Science students for employment in the enterprises culture, Journal of Geography in Higher Education, 25, no 1, s. $121-126$.

Minkiewicz B., 2001, Analiza ścieżek edukacyjnych i zawodowych absolwentów, [w:] Biogramy edukacyjne, red. B. Minkiewicz, T. Szapiro, Ośrodek Wydawniczo-Poligraficzny SIMP - Hanna Bicz, Warszawa.

Orczykowska A. 2006, Szkolnictwo wyższe a wymagania rynku pracy, Nauka i Szkolnictwo Wyższe, nr 2, s. 49-64.

Owen E., 2001, What skills do employers need?, Journal of Geography in Higher Education, 25, no 1, s. $121-126$.

Paśko J., 2008, Ksztatcenie dla przyjemności czy dla potrzeb, [w:] Dylematy edukacyjne wspótczesnego człowieka a jakość ksztatcenia w szkole wyższej, red. B. Sitarska, R. Droba, K. Jankowski, Wyd. Akademii Podlaskiej, Siedlce, s. 293-299.

Piróg D., Piróg S., 2007, Pożądane umiejętności absolwentów nauczycielskich studiów geograficznych na rynku pracy $w$ procesie przemian spoleczno-gospodarczych $w$ Polsce, [w:] Procesy transformacji spoleczno-ekonomicznych i przyrodniczych struktur przestrzennych, red. J. Lach, M. Borowiec, T. Rachwał, Wyd. Naukowe AP, Kraków, s. 631-645. 
Rooney P., Kneale P., Gambini B., Keiffer A., Vandrasek B., Gedye S., 2006, Variations in international understandings of employability for geography, Journal of Geography in Higher Education, 30, no 1 , s. 133-145.

Rynek pracy a studia bibliotekoznawstwa i informacji naukowej w Polsce, red. M. Kocójowa, Wyd. UJ, Kraków, 1997.

Struder I., 2006, Enterprising geography, earth and environmental science students, Planet, no 16, s. $26-39$.

Sztanderska U., Minkiewicz B., Bąba M., 2005a, Absolwent na rynku pracy. [Cz. 1], Forum Akademickie R. 12 , nr 6, s. 32-34.

Sztanderska U., Minkiewicz B., Bąba M., 2005b, Absolwent na rynku pracy. [Cz. 2], Forum Akademickie R. $12, \mathrm{nr} 7 / 8$, s. $42-44$.

Tomaszek-Plewa H., 2001, Losy absolwentów Wydziału Wychowania Muzycznego Akademii Muzycznej we Wrocławiu, Zeszyt Naukowy, Akademia Muzyczna im. Karola Lipińskiego we Wrocławiu, nr 79 , s. 95-103.

\title{
Educational services on an academic level in the context of the demands of the labour market
}

The transformation of the political system in Poland brought, apart from obvious profits, a number of negative consequences. One of the crucial socio-economic problems is unemployment, which also affects the graduates of higher education. One of the most important reasons for this unfavourable situation is traditional concept of academic education, not always correlating with the needs of employers. Previous curricula strategies resulted in some majors being perceived as a pass to low paid occupations or unemployment.

According to many scholars, thinking about academic education mainly as the step for being employed after graduation is oversimplifying the role of higher education. This outlook does not take into consideration very dynamic changes in services (also educational services on an academic level) in socio-economic development and the fact that one of the principal purposes of modern higher education is to produce graduates who are able to succeed in the workplace and who can make worthwhile contributions to organisations where they are employed. Such aspirations are common for candidates for students who estimate the probability of finding a good job after graduation. The experiences of the West European countries in this area show that in few years it will be very important to design such curricula which provide education as close to employers' expectations of the graduates as possible.

The paper presents the results of the literature studies concerning modern concepts of higher education in reference to the needs of the labour market.

\author{
dr Danuta Piróg \\ Uniwersytet Pedagogiczny w Krakowie \\ Instytut Geografii \\ Zakład Dydaktyki Geografii \\ e-mail: dbutryn@up.krakow.pl
}

